\title{
Pengaruh Akuntansi Pertanggungjawaban pada Efektivitas Pengendalian Biaya dengan Motivasi Kerja sebagai Pemoderasi
}

\author{
Komang Ayusta Devi Savitri1 \\ Fakultas Ekonomi dan Bisnis \\ Universitas Udayana, Indonesia
}

\author{
Ni Putu Sri Harta Mimba² \\ Fakultas Ekonomi dan Bisnis \\ Universitas Udayana, Indonesia
}

\begin{abstract}
Surel : ayustadevi@gmail.com
ABSTRAK

Suatu pusat perbelanjaan memiliki kegiatan operasional yang luas sehingga manajer tidak mampu melakukan pengendalian biaya tanpa bantuan pihak lain. Diperlukan penerapan akuntansi pertanggungjawaban dalam membantu mengaktualisasi pendelegasian wewenang dan tanggungjawab guna tercapainya pengendalian biaya yang efektif. Tujuan dari penelitian ini adalah untuk mendapatkan bukti empiris mengenai pengaruh penerapan akuntansi pertanggungjawaban pada efektivitas pengendalian biaya dengan motivasi kerja sebagai pemoderasi Penelitian ini dilakukan dengan mengambil populasi pusat perbelanjaan di Kabupaten Gianyar. Melalui metode sampling jenuh peneliti memperoleh sampel penelitian berjumlah 37 sampel. Teknik analisis yang digunakan adalah Moderate Regression Analysis. Hasil penelitian yang diperoleh adalah akuntansi pertanggungjawaban berpengaruh positif pada efektivitas pengendalian biaya. Serta motivasi kerja mampu memoderasi hubungan penerapan akuntansi pertanggungjawaban pada efektivitas pengendalian biaya.
\end{abstract}

Kata Kunci: Akuntansi Pertanggungjawaban; Pengendalian Biaya; Motivasi Kerja.

\section{Effect of Accountability on the Effectiveness of Cost Control with Work Motivation as a Moderator}

\section{ABSTRACT}

A shopping center has extensive operational activities so that managers are unable to control costs without the help of other parties. Required application of responsibility accounting in helping to actualize the delegation of authority and responsibility in order to achieve effective cost control. The purpose of this study is to obtain empirical evidence about the effect of the application of accountability accounting on the effectiveness of cost control with work motivation as a moderating research. This study was conducted by taking the population of shopping centers in Gianyar Regency. Through the saturated sampling method the researcher obtained 37 research samples. The analysis technique used is Moderate Regression Analysis. The results obtained are the responsibility of accounting has a positive effect on the effectiveness of cost control. And work motivation is able to moderate the relationship between the application of responsibility accounting to the effectiveness of cost control.

Keywords: Responsibility Accounting; Cost Control; Work Motivation.

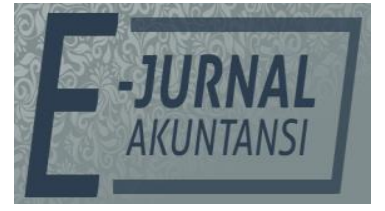

e-ISSN 2302-8556

Vol. 30 No. 8

Denpasar, Agustus 2020

Hal. 1927-1940

DOI:

10.24843/EJA.2020.v30.i08.p03

PENGUTIPAN:

Savitri, K. A. D. \& Mimba, N. P. S. H. (2020). Pengaruh Akuntansi

Pertanggungjawaban pada

Efektivitas Pengendalian Biaya dengan Motivasi Kerja Sebagai Pemoderasi. E-Jurnal Akuntansi, 30(8), 1927-1940

RIWAYAT ARTIKEL: Artikel Masuk: 11 Februari 2020 Artikel Diterima: 22 Juli 2020

Artikel dapat diakses : https://ojs.unud.ac.id/index.php/Akuntansi/index 


\section{PENDAHULUAN}

Pada umumnya perusahaan melakukan pengendalian biaya karena hal ini dapat mengendalikan biaya yang terjadi dalam menjalankan kegiatan sehingga dapat bejalan dengan efektif dan efisien. Setiap perusahaan baik yang berskala besar maupun berskala kecil pada umumnya berorientasi untuk mencapai laba. Keberhasilan perusahaan untuk pencapaian laba yang diinginkan dipengaruhi oleh pengendalian biaya yang dilakukan. Pengendalian biaya adalah bagaimana manajemen mengambil tindakan dalam mengarahkan aktivitas yang sedang dilaksanakan agar berjalan sesuai dengan tujuan yang telah ditetapkan. Pengendalian biaya sebagai manajemen atau biaya penahan dan didefinisikan sebagai aset set luas metode akuntansi biaya dan teknik manajemen dengan tujuan meningkatkan efisiensi daerah tertentu seperti departemen, divisi atau lini produk dalam operasi tertentu (Siyanbola \& Raji, 2013). Pengendalian merupakan suatu usaha untuk mengarahkan proses pada rencana yang telah ditentukan. Menurut Wei et al., (2014) keuntungan dari pengendalian biaya adalah memberikan informasi yang tepat mengenai biaya kontrol perusahaan dan berorientasi untuk mengontrol kegiatan perusahan yang beroperasi dalam lingkungan perusahaan. Salah satu alat yang dapat digunakan untuk proses perencanaan dan pengendalian adalah anggaran (Novitasari \& Wirama, 2016). Penetapan tujuan juga memerlukan keterlibatan dalam perencanaan untuk mengembangkan strategi yang akan dilakukan dalam pencapaian tujuan (Arthana et al., 2016). Menurut Hafidz (2007) untuk dapat mencapai tujuan yang ditetapkan, suatu proses pengendalian haruslah melalui beberapa prosedur seperti menetapkan standar (anggaran) yang dijadikan sebagai tolak ukur, mencatat hasil atas realisasi, serta melakukan perbandingan antara pelaksanaan hasil realisasi dengan standar-standar yang telah ditetapkan. Pengendalian biaya ini dapat dilakukan melalui anggaran biaya yang secara kontinu diadakan pengawasan secara analisis terhadap penyimpangan yang terjadi sehingga dapat diketahui penyebab terjadinya penyimpangan atas selisih tersebut kemudian dilakukan tindak lanjut agar kerugian yang terjadi relatif kecil tidak merugikan perusahaan (Effendy et al., 2015). Anggaran merupakan salah satu alat yang digunakan perusahaan untuk mengendalikan biaya. Selain itu anggaran merupakan salah satu cara manajemen dalam melakukan pengendalian terhadap biaya. Anggaran merupakan rencana kerja tiap-tiap organisasi yang disusun secara sistematis guna dijadikan sebagai alat perencanaan dan pengendalian guna pencapaian tujuan yang telah ditetapkan. Menurut Anthony \& Govindarajan (2005) anggaran merupakan alat penting untuk perencanaan pengendalian jangka pendek yang efektif dalam organisasi. Anggaran dapat berfungsi dengan baik karena didukung oleh struktur organisasi perusahaan yang memadai. Sehingga dengan memiliki struktur organisasi yang memadai, sesuai dengan salah satu syarat dari akuntansi pertanggungjawaban yaitu anggaran. Anggaran yang disusun secara partisipatif dapat meningkatkan kinerja manajer dimana disusun secara bersama-sama dan perlu disetujui maka secara tidak langsung setiap individu atau karyawan akan terdorong dan termotivasi untuk mencapai tujuan yang ditetapkan. Dorongan tersebut muncul karena adanya suatu kebutuhan yang terarah pada pencapaian tujuan yang ditetapkan (Anggarini \& Sujana, 2016). Kompetensi seorang pegawai memiliki 
pengaruh pada kinerja yang diperoleh untuk mencapai tujuan (Zaim et al., 2013). Selain itu, Komitmen organisasi juga dapat berfungsi sebagai alat bantu psikologis bagi pegawai untuk melakukan pekerjaannya, sehingga dapat mencapai hasil yang diinginkan (Wentzel, 2002). Setiap manajer dalam tiap unit departemen dalam melakukan penyusunan anggaran akan merencanakan biaya yang menjadi tanggung jawabnya di bawah koordinasi manajemen puncak (Sriwidodo, 2010). Keterlibatan manajer dalam penyusunan anggaran dan kerjasama yang terjalin dalam pusat pertanggungjawaban mempengaruhi keefektivitasan (Nyakuwanika et al., 2012).

Pusat perbelanjaan memiliki kegiatan operasional yang cukup luas dan komplek sehingga manajer dalam sebuah pusat perbelanjaan tidak mampu melakukan pengendalian biaya tanpa bantuan pihak lain. Oleh karena itu, manajer lini atas melakukan pendelegasian wewenang dan tanggungjawab kepada kepala bagian tiap-tiap unit departemen yang ada dipusat perbelanjaan tersebut untuk bertanggungjawab atas seluruh kegiatan yang ada dibawah kendalinya. Sehingga dapat mempermudah dalam proses pengendalian biaya, guna tercapainya pengendalian biaya yang efektif. Diperlukan adanya penerapan akuntansi pertanggungjawaban dalam membantu mengaktualisasi pendelegasian wewenang dan tanggungjawab yang ada. Hal ini dikarenakan akuntansi pertanggungjawaban adalah salah satu alat terbaik dalam manajemen biaya yang digunakan dalam perusahaan atau organisasi yang memiliki ruang lingkup yang besar dalam melakukan desentralisasi dan divisional untuk mengelola perusahaan (Fowzia, 2011). Akuntansi pertanggungjawaban dalam penerapannya mempunyai syarat-syarat antara lain: struktur organisasi, perencanaan anggaran, pelaksanaan pengendalian dan pelaporan (Setiyanto \& Norafyana, 2017). Penerapan akuntansi pertanggungjawaban menjadi penting untuk mengetahui pelaksanaan tanggung jawab manajer dalam mengendalikan pendapatan dan biaya sehingga perusahaan juga bisa menilai kinerja manajer pertanggungjawaban (Prang, 2014). Akuntansi pertanggunjawaban yang dilakukan manajemen bertujuan untuk memeriksa keefektifan penyelesaian rencana dan untuk mendeteksi penyimpangan yang mungkin terjadi. Apabila terdapat kelemahan dan kekurangan dalam rencana kebijakan dapat diatasi dengan cepat dan tepat (Damayanti, 2004). Akuntansi pertanggungjawaban merupakan sistem yang mengukur berbagai hasil yang dicapai oleh setiap pusat pertanggungjawaban menurut informasi yang dibutuhkan oleh para manajer untuk mengoperasikan pusat pertanggungjawaban mereka (Bahtiar, 2013). Pusat pertanggungjawaban dibentuk untuk menyelaraskan antara tujuan individu dan tujuan perusahaan. Pusat pertanggungjawaban muncul karena adanya pelimpahan wewenang, dimana orang yang menerima wewenang mempunyai suatu kewajiban untuk melaksanakan serangkaian tindakan dan mempertanggungjawabkan kepada pemberi wewenang (Andriana \& Balqis, 2015).

Pusat perbelanjaan merupakan tempat penjual dan pembeli bertransaksi baik secara eceran atau retail yang lokasinya berada dalam satu bangunan. Tempat ini dikatakan pusat perbelanjaan, karena tempat ini menjadi sarana rekreasi dan hiburan yang memenuhi hampir semua kebutuhan masyarakat, dimulai dari kebutuhan pangan hingga sandang dan sarana rekreasi keluarga. 
Dalam sebuah pusat perbelanjaan, selain pengunjung dapat membeli kebutuhannya, pengunjung dapat berjalan-jalan, menikmati hiburan, makan, dan melakukan berbagai kegiatan lain (Ardiani \& Wirasedana, 2013). Dalam proses pengendalian biayanya, manajemen di suatu pusat perbelanjaan membentuk pusat-pusat pertanggungjawaban. Pusat pertanggungjawaban dalam suatu pusat perbelanjaan adalah unit-unit departemen yang memiliki kepala bagian departemen masing-masing yang bertanggung jawab atas seluruh kegiatan yang ada pada departemen yang dipimpin. Setiap departemen menyusun rencana program serta anggaran dan melakukan penyusunan laporan pertanggungjawaban. Pusat biaya merupakan salah satu pusat pertanggungjawaban, dimana unit departemennya hanya bertanggung jawab atas biaya-biaya yang terjadi tanpa menghubungkannya dengan keluaran yang dihasilkan (Ardiani \& Wirasedana, 2013). Suatu organisasi harus meningkatkan keragaman ukuran kinerja mereka untuk menggunakan ukuran keuangan dan nonkeuangan untuk mengevaluasi kinerja (Sholihin et al., 2010).

Dalam proses pengendalian biaya diperlukan adanya penerapan akuntansi pertanggungjawaban. Akuntansi pertanggungjawaban dapat dijadikan suatu sistem kontrol yang penting sebagai sumber informasi guna memfasilitasi proses dalam pengambilan keputusan jangka pendek ataupun jangka panjang (Al-shomaly, 2013). Dengan diterapkannya akuntansi pertanggungjawaban maka dapat diketahui siapa saja yang bertanggung jawab atas kinerja yang dihubungkan dengan wewenang yang dimiliki tiap manajer (Watung et al., 2014). Menurut Andani et al., (2017) syarat-syarat utama dalam membentuk dan mempertahankan akuntansi pertanggungjawaban dapat dilaksanakan dengan cara: (1) menentukan garis wewenang dan tanggung jawab secara jelas bagi setiap tingkatan manajemen yang tersaji melalui struktur organisasinya; (2) mencatat dan menilai pegawai sesuai dengan garis wewenang dan tanggung jawab masing-masing; (3) menyusun sistem administrasi yang sesuai dengan garis wewenang dan tanggung jawab yang telah ditentukan, yang diajukan dalam anggaran; dan (4) terdapat pengendalian biaya sesuai dengan sistem akuntansi biaya dan adanya pelaporan biaya secara rutin dari masingmasing departemen. Salah satu hal yang penting diperhatikan dalam proses pengendalian biaya adalah adanya perencanaan anggaran. Dalam perencanaan anggaran, manajer dapat berpartisipasi dalam penyusunan perencanaan anggaran. Partisipasi penyusunan anggaran menyediakan kesempatan bawahan untuk berinteraksi dan berkomunikasi dengan atasannya bahkan mampu mempengaruhi target anggaran yang ingin mereka peroleh (Lau \& Tan, 2003). Dalam penelitian yang dilakukan Nyakuwanika et al., (2012) mengemukakan keterlibatan manajer dalam penyusunan anggaran dan kerjasama yang terjalin antar pusat pertanggungjawaban dapat mempengaruhi keefektivitasan pengendalian biaya. Selain itu, menurut Ardiani \& Wirasedana (2013) Akuntansi pertanggungjawaban dikatakan mampu memberikan pengaruh terhadap efektivitas pengendalian biaya (Ardiani \& Wirasedana, 2013). Dalam penelitian Pomes (2016) ditemukan terdapat hubungan positif dan tidak signifikan antara anggaran akuntansi pertanggungjawaban terhadap efektivitas pengendalian biaya. 
Penelitian yang dilakukan oleh (Ardiani \& Wirasedana (2013) yang menguji pengaruh penerapan akuntansi pertanggungjawaban terhadap efektivitas pengendalian biaya, didapatkan hasil bahwa terdapat hubungan positif antara penerapan akuntansi pertanggungjawaban dengan efektivitas pengendalian biaya. Semakin baik penerapan akuntansi pertanggungjawaban maka keefektivitasan pengendalian biaya akan mengalami peningkatan, sebaliknya semakin buruk penerapan akuntansi pertanggungjawaban maka keefektivitasan pengendalian biaya akan mengalami penurunan pada suatu pusat perbelanjaan. Selain itu didukung juga dengan penelitian yang dilakukan oleh (Bahtiar, 2013) yang menguji hubungan akuntansi pertanggungjawaban dengan efektivitas pengendalian biaya juga menunjukkan bahwa adanya hubungan positif antara penerapan akuntansi pertanggungjawaban dengan pengendalian biaya. Berdasarkan uraian tersebut maka dapat dibuat hipotesis sebagai berikut.

$\mathrm{H}_{1}$ : Penerapan Akuntansi Pertanggungjawaban berpengaruh Positif pada Efektivitas Pengendalian Biaya.

Akuntansi pertanggungjawaban merupakan sistem yang mengukur berbagai hasil yang dicapai oleh setiap pusat pertanggungjawaban menurut informasi yang dibutuhkan oleh para manajer untuk mengoperasikan pusat pertanggungjawaban mereka (Bahtiar, 2013). Nyakuwanika et al., (2012) mengemukakan keterlibatan manajer dalam penyusunan anggaran dan kerjasama yang terjalin antar pusat pertanggungjawaban dapat mempengaruhi keefektivitasan pengendalian biaya. Sehingga dalam proses penyusunan anggaran, partisipasi manajer mempengaruhi efektivitas pengendlian biaya. Menurut Brownell (1982) partisipasi penyusunan anggaran merupakan seberapa luasnya individu terlibat dan memiliki pengaruh dalam kegiatan penyusunan anggaran. Anggaran yang disusun secara parisipatif dapat meningkatkan kinerja manajer, di mana disusun secara bersama-sama dan perlu persetujuan manajer lini. Sehingga secara tidak langsung karyawan lainnya akan ikut termotivasi untuk mencapai tujuan yang ditetapkan. Dapat dikatakan, dorongan tersebut muncul dikarenakan adanya tujuan yang ingin dicapai. Sehingga keterlibatan, kerjasama, dan motivasi kerja yang dilakukan akan berpengaruh kepada keefektivitasan pengendalian yang dilakukan manajer. Goal setting theory berkaitan dengan hal ini, di mana goal setting theory mengungkapkan mengenai hubungan tujuan yang ditetapkan dengan prestasi yang dihasilkan. Dapat dikatakan, dengan adanya tujuan yang ingin diraih yaitu laba dan adanya pelaporan yang dilaporakan kepada manajer lini atas, maka dapat memotivasi manajer di pusat pertanggungjawaban dan karyawan dalam mencapai tujuan perusahaan yaitu laba.

Salah satu hal yang dapat memotivasi masing-masing pusat pertanggungjawaban dalam mencapai pengendalian biaya yang memadai yakni dengan adanya pelaporan atas hasil yang telah dicapai setiap periodenya. Safa (2012) menyatakan pelaporan yang dilakukan berupa pelaporan informasi akuntansi pertanggungjawaban yang berisikan informasi mengenai biaya yang berada langsung di bawah tanggung jawabnya dan dilaporkan dalam bentuk laporan pertanggungjawaban. Hal ini bertujuan untuk memotivasi karyawan dalam mencapai sasaran organisasi dan dalam mematuhi standar perilaku yang 
telah ditetapkan agar membuahkan tindakan dan hasil yang diinginkan. Motivasi karyawan untuk berusaha, dipengaruhi oleh nilai penghargaan dan kemungkinan usaha akan diberi penghargaan (Napitupulu \& Widodo, 2014). Menurut Sinambela (2010:6) Jika tidak memiliki target atau standar yang ditetapkan dalam pengukuran, maka kinerja seseorang atau kinerja sekumpulan tidak mungkin dapat diketahui, hal tersebut juga dipengaruhi oleh adanya motivasi. Sistem penilaian kinerja yang efektif adalah yang dapat memudahkan manajer puncak untuk melaksanakan pengendalian dan memberikan motivasi kepada para manajer lini guna memperbaiki dan meningkatkan kinerjanya (Sosik et al., 2011). Motivasi kerja adalah upaya perusahaan dalam menggerakkan dan mengarahkan karyawan agar bekerja sama, bekerja efektif, dan melaksanakan pekerjaanya dengan penuh kesadaran, kegairahan dan bertanggung jawab sehingga nantinya mampu mencapai sasaran dan tujuan dari perusahaan tersebut. Jadi, motivasi kerja juga dapat dikatakan sebagai pendorong semangat karyawan untuk bekerja lebih baik lagi. Mia (1988) menyebutkan bahwa proses penyusunan anggaran akan berjalan lebih efektif pada kondisi karyawan yang memiliki motivasi tinggi begitu juga sebaliknya. Dari definisi tersebut dapat disimpulkan bahwa orang akan memiliki motivasi untuk berusaha jika ia memiliki nilai penghargaan yang tinggi atau berkeyakinan bahwa suatu kinerja akan diberi penghargaan adalah tinggi jika sesuai dengan yang ditetapkan. Berdasarkan penelitiaannya, menurut Herzberg ada dua faktor yang mempengaruhi motivasi pekerja dalam melaksanakan pekerjaannya (Teori Dua Faktor).

Penelitian Anggarini \& Sujana (2016) yang menguji pengaruh partisipasi anggaran pada kinerja manajerial dengan motivasi kerja sebagai variabel pemoderasi, mendapatkan hasil bahwa motivasi berpengaruh positif pada hubungan antara partisipasi anggaran pada kinerja manajerial. Serta menunjukkan variabel motivasi mampu memoderasi dan memperkuat hubungan antara pasrtisipasi anggaran terhadap kinerja manajerial. Selain itu, penelitian Dewi dan Ferayani (2019) mengenai motivasi memoderasi pengaruh sistem pengendalian intern dan partisipasi penyusunan anggaran pada kinerja individu, mendapatkan hasil bahwa motivasi kerja mampu memperkuat hubungan sistem pengendalian intern dan keikutsertaan dalam menyusun anggaran pada kinerja individu. Berdasarkan uraian tersebut, dapat dirumuskan hipotesis sebagai berikut.

$\mathrm{H}_{2}$ : Motivasi Kerja Memoderasi (Memperkuat) Pengaruh Penerapan Akuntansi Pertanggungjawaban pada Efektivitas Pengendalian Biaya.

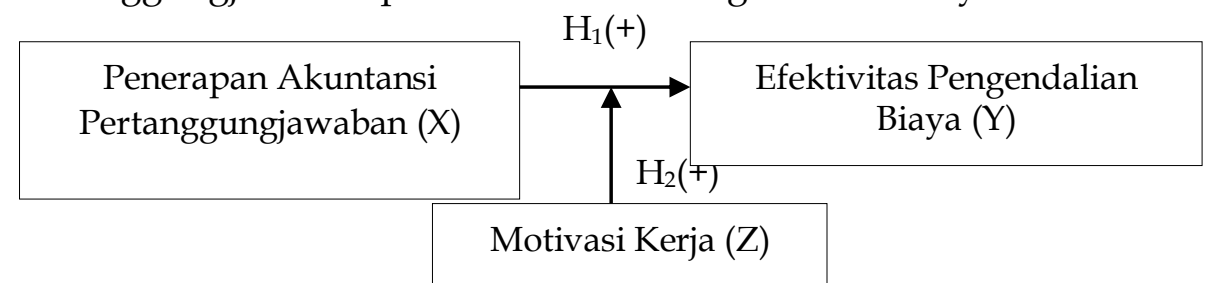

\section{Gambar 1. Model Penelitian}

Sumber: Data Penelitian, 2019

Penelitian ini menggunakan teori agensi sebagai landasan teori. Teori agensi pertama kali dipopulerkan oleh Jensen dan Meckling pada tahun 1976. 
Teori agensi adalah teori yang dibuat berdasarkan pada hubungan keagenan antara agen dan principal (Jensen \& Meckling, 1976). Kemudian teori kedua yaitu Goal Setting Theory. Goal Setting Theory dikemukakan oleh Locke (1978). Teori ini menjelaskan mengenai hubungan antara tujuan yang ditetapkan dengan prestasi kerja (kinerja). Konsep dasar teori ini adalah seseorang yang memahami tujuan yang diharapkan organisasi kepadanya, yang akan mempengaruhi perilaku kerjanya.

\section{METODE PENELITIAN}

Penelitian ini digambarkan dengan pendekatan kuantitatif. Penelitian ini menjelaskan pengaruh penerapan akuntansi pertanggungjawaban pada efektivitas pengendalian biaya dengan motivasi kerja sebagai variabel moderasi. Penelitian ini dilakukan di pusat perbelanjaan di Kabupaten Gianyar. Metode pengumpulan data dalam penelitian ini menggunakan kuesioner. Daftar perbelanjaan yang di jadikan lokasi penelitian ini ditunjukkan oleh Tabel 1.

\section{Tabel 1. Daftar Pusat Perbelanjaan di Kabupaten Gianyar}

\begin{tabular}{cl}
\hline No & \multicolumn{1}{c}{ Nama Perusahaan } \\
\hline 1 & Arta Sedana Supermarket \& Departement Store \\
2 & Harum Fajar \\
\hline
\end{tabular}

Sumber: Data Penelitian, 2019

Objek dalam penelitian ini adalah akuntansi pertanggungjawaban, pengendalian biaya, serta motivasi kerja pusat perbelanjaan di Kabupaten Gianyar. Variabel bebas dalam penelitian ini adalah akuntansi pertanggungjawaban $(X)$. Sedangkan variabel terikat dalam penelitian ini adalah efektivitas pengendalian biaya $(\mathrm{Y})$. Serta variabel moderasi dalam penelitian ini adalah motivasi kerja $(Z)$. Jenis data dalam penelitian ini yaitu kuantitatif yang diperoleh dari data kualitatif yang dikuantitatifkan dengan bantuan skala Likert yang mengacu pada pengukuran variabel yang digunakan. Data kuantitatif dalam penelitian ini adalah skor yang berasal dari hasil jawaban kuesioner yang diisi oleh responden. Penelitian ini menggunakan data primer berupa kuesioner. Populasi dalam penelitian ini adalah pusat perbelanjaan di Kabupaten Gianyar dengan sampel yaitu karyawan yaitu berjumlah 37 responden. Hipotesis dalam penelitian ini diuji dengan menggunakan model moderasi (Moderate Regression Analysis). Model Moderate Regression Analysis dirancang untuk menentukan hubungan antara dua variabel yang dipengaruhi oleh variabel ketiga atau variabel moderating.

Berdasarkan rumusan masalah serta hipotesis penelitian yang telah dipaparkan, dapat diidentifikasi akuntansi pertanggungjawaban (X) sebagai variabel independen diukur dengan skala Likert 1-4 yaitu 1= Sangat Tidak Setuju (STS), 2= Tidak Setuju (TS), 3= Setuju (S), dan 4= Sangat Setuju (SS) dengan jumlah pernyataan yaitu sebanyak 26 pernyataan. Efektivitas pengendalian biaya (Y) sebagai variabel dipenden diukur dengan skala Likert 1-4 yaitu 1= Sangat Tidak Setuju (STS), 2= Tidak Setuju (TS), 3= Setuju (S), dan 4= Sangat Setuju (SS) dengan jumlah pernyataan yaitu sebanyak 11 pernyataan. Motivasi kerja $(Z)$ sebagai variabel moderasi dengan skala Likert 1-4 yaitu 1= Sangat Tidak Setuju 
(STS), 2= Tidak Setuju (TS), 3= Setuju (S), dan 4= Sangat Setuju (SS) dengan jumlah pernyataan yaitu sebanyak 16 pernyataan.

\section{HASIL DAN PEMBAHASAN}

Pengumpulan data penelitian dilakukan melalui penyebaran kuesioner kepada 38 orang karyawan di 2 pusat perbelanjaan di Kabupaten Gianyar, yaitu Arta Sedana Supermarket \& Departement Store dan Harum Fajar yang kemudian jumlah kuesiner yang dikembalikan yaitu sebanyak 37 kuesioner. Hasil kuesioner penelitian ditunjukkan pada tabel 2.

\section{Tabel 2. Rincian Pengriminan dan Pengembalian Kuesioner}

\begin{tabular}{lc}
\hline Keterangan & Jumlah \\
\hline Kuesioner yang disebar & 38 \\
Kuesioner yang tidak kembali & 1 \\
Kuesioner yang dikembalikan & 37 \\
Kuesioner yang digunakan & 37 \\
Tingkat pengembalian (Respons rate) & \\
Kuesioner yang dikembalikan $\times 100 \%$ & $97,36 \%$ \\
Kuesioner yang dikirim & \\
Tingkat pengembalian yang digunakan (useable response rate) & $100 \%$ \\
Kuesioner yang diolah $\times 100 \%$ & \\
\hline Kuesioner yang dikirim & \\
\hline
\end{tabular}

Sumber: Data Penelitian, 2019

Berdasarkan Tabel 2, menunjukkan bahwa kuesioner yang disebar yaitu sebanyak 38 buah eksemplar dengan tingkat pengembalian sebesar 97,36 persen. Sehingga jumlah kuesioner yang digunakan dalam penelitian ini yaitu 37 buah.

Berdasarkan kuesioner yang telah disebarkan kepada responden yang berjumlah 37 orang, terdapat beberapa karakteristik responden. Karakteristik responden penelitian ditunjukkan pada tabel 3.

\section{Tabel 3. Karakteristik Responden}

\begin{tabular}{|c|c|c|c|c|}
\hline No & Variabel & Klasifikasi & $\begin{array}{l}\text { Jumlah } \\
\text { (Orang) }\end{array}$ & Persentase \\
\hline \multirow[t]{3}{*}{1} & Jenis Kelamin & Laki - Laki & 9 & 24,32 \\
\hline & & Perempuan & 28 & 75,68 \\
\hline & Jumlah & & 37 & 100 \\
\hline \multirow[t]{6}{*}{2} & Lama Bekerja & 1 - 5 Tahun & 22 & 59,46 \\
\hline & & $6-10$ Tahun & 5 & 13,51 \\
\hline & & $11-15$ Tahun & 5 & 13,51 \\
\hline & & 16 - 20 Tahun & 2 & 5,41 \\
\hline & & $\geq 21$ Tahun & 3 & 8,11 \\
\hline & Jumlah & & 37 & 100 \\
\hline \multirow[t]{6}{*}{3} & Tingkat & SLTA/Sederajat & 31 & 83,78 \\
\hline & Pendidikan & Diploma (D3) & 1 & 2,71 \\
\hline & & Strata 1 (Sarjana) & 5 & 13,51 \\
\hline & & Strata 2 (Magister) & 0 & 0 \\
\hline & & Strata 3 (Doktor) & 0 & 0 \\
\hline & Jumlah & & 37 & 100 \\
\hline
\end{tabular}

Sumber: Data Penelitian, 2019

Penelitian ini menggunakan uji Moderate Regression Analysis untuk mengetahui pengaruh akuntansi pertanggungjawaban $(X)$ yang di moderasi oleh 
motivasi kerja (Z), pada efektivitas pengendalian biaya $(\mathrm{Y})$ pada pusat perbelanjaan di Kabupaten Gianyar. Hasil dari pengujian MRA dari variabel dalam penelitian ini disajikan dalam tabel 4.

Tabel 4. Hasil Uji Moderate Regression Analysis

\begin{tabular}{|c|c|c|c|c|c|}
\hline Variabel Terikat & $\begin{array}{c}\text { Variabel } \\
\text { Bebas }\end{array}$ & $\begin{array}{c}\text { Koefisien } \\
\text { Regresi }\end{array}$ & $\begin{array}{c}\text { Standar } \\
\text { Error }\end{array}$ & $\mathrm{t}$ hitung & Sig. \\
\hline \multirow{3}{*}{ Motivasi Kerja } & $X$ & 0,286 & 0,070 & 4,099 & 0,000 \\
\hline & $\mathrm{Z}$ & 0,133 & 0,97 & 1,381 & 0,177 \\
\hline & $X Z$ & 0,002 & 0,001 & 2,275 & 0,030 \\
\hline Constant & $-3,283$ & & F- Hitung & 39,395 & \\
\hline Anjusted R Square & 0,782 & & Sig. & 0,000 & \\
\hline
\end{tabular}

Sumber: Data Penelitian, 2019

Berdasarkan Tabel 4, diperoleh hasil sebagai berikut:

$$
\begin{array}{lll}
\alpha & =\text { Konstanta } & =-3,283 \\
\beta_{1} & =\text { Koefisien Regresi variabel X } & =0,286 \\
\beta_{2} & =\text { Koefisien Regresi variabel Z } & =0,133 \\
\beta_{3} & =\text { Koefisien Regresi variabel XZ } & =0,002
\end{array}
$$

Persamaan garis linier bergandanya adalah:

$$
\mathrm{Y}=-3,283+0,286 \mathrm{X}+0,133 \mathrm{Z}+0,002(\mathrm{XZ})
$$

Berdasarkan persamaan regresi model tersebut, konstanta sebesar -3,283 artinya apabila akuntansi pertanggungjawaban $(X)$, dan motivasi kerja $(Z)$ sama dengan nol, maka pengendalian biaya $(Y)$ sebesar $-3,283$. Koefisien regresi dari variabel akuntansi pertanggungjawaban $(X)$ adalah sebesar 0,286 artinya terdapat pengaruh positif antara variabel akuntansi pertanggungjawaban pada efektivitas pengendalian biaya $(Y)$ sebesar 0,286. Koefisien regresi variabel motivasi kerja $(Z)$ 0,133 artinya bahwa terdapat pengaruh positif antara variabel motivasi kerja $(Z)$ pada variabel efektivitas pengendalian biaya $(Y)$ sebesar 0,133. Nilai koefisien regresi $(X Z)$ sebesar 0,002 menunjukkan bahwa dengan adanya variabel $\mathrm{Z}$ maka pengaruh $\mathrm{X}$ pada $\mathrm{Y}$ akan semakin diperkuat.

Berdasarkan Tabel 4, menunjukkan bahwa besarnya nilai koefisien determinasi ditunjukkan dengan niali adjusted $\mathrm{R}$ aquare $\left(\mathrm{R}^{2}\right)$ adalah 0,782 . Hal ini berarti bahwa variabel penerapan akuntansi pertanggungjawaban $(X)$, motivasi kerja $(\mathrm{Z})$, interaksi $\mathrm{XZ}$ terhadap efektivitas pengendalian biaya $(\mathrm{Y})$ sebesar 78,2 persen dan sisanya sebesar 21,8 persen dipengaruhi oleh faktor-faktor lain di luar model penelitian. Hal yang perlu diperhatikan sebelum melakukan pengujian hipotesis yaitu kelayakan model penelitian yang dilakukan dengan uji $\mathrm{F}$ untuk mengetahui pengaruh variabel independen pada variabel dependen. Hasil pengolahan data pada Tabel 4 dengan menggunakan program SPSS diperoleh nilai $F_{\text {hitung }}$ sebesar 39,395 Dengan signifikansi 0,000 < 0,05 maka dapat diartikan bahwa pada kelompok yang diuji memiliki perbedaan yang nyata (signifikan). Hasil tersebut memiliki arti bahwa secara simultan (bersama-sama) variabel independen berpengaruh pada variabel dependen. Sehingga model penelitian ini dapat dikatakan layak digunakan sebagai model regresi moderasi.

Uji hipotesis dilakukan untuk mengetahui seberapa besar pengaruh variabel independen terhadap variabel dependen secara parsial. Hipotesis yang pertama yaitu, pengaruh akuntansi pertanggungjawaban $(X)$ pada efektiivitas pengendalian biaya $(\mathrm{Y})$ dengan $\mathrm{H}_{0}$ : Akuntansi Pertanggungjawaban tidak 
berpengaruh pada efektivitas pengendalian biaya, serta $H_{1}$ : Akuntansi pertanggungjawaban berpengaruh positif dan signifikan pada efektivitas pengendalian biaya. Berdasarkan hasil analisis dalam Tabel 4 diperoleh hasil analisis pengaruh penerapan akuntansi pertannggungjawaban terhadap efektivitas pengendalian biaya yaitu nilai signifikasi sebesar 0,000 dengan nilai koefisien positif sebesar 0,286. Nilai signifikasi sebesar 0,000 $<0,05$ berarti bahwa $\mathrm{H}_{0}$ ditolah dan $\mathrm{H}_{1}$ diterima. Hal ini berarti bahwa akuntansi pertanggungjawaban berpengaruh positif dan signifikan terhadap efektivitas pengendalian biaya.

Hipotesis kedua yaitu, pengaruh motivasi kerja $(Z)$ sebagai mediator akuntansi pertanggungjawaban $(X)$ pada efektivitas pengendalian biaya $(Y)$ dengan $\mathrm{H}_{0} \quad$ : Motivasi kerja tidak mempengaruhi hubungan antara akuntansi pertanggungjawaban pada efektivitas pengendalian biaya, serta $\mathrm{H}_{1}$ : Motivasi kerja mempengaruhi hubungan antara akuntansi pertanggungjawaban pada efektivitas pengendalian biaya. Berdasarkan hasil analisis dalam Tabel 4 diperoleh hasil signifikansi sebesar 0,030 dengan nilai koefisien positif sebesar 0,002. Nilai signifikasi sebesar 0,030 $<0,05$ berarti bahwa $\mathrm{H}_{0}$ ditolak dan $\mathrm{H}_{1}$ diterima. Hal ini berarti bahwa motivasi kerja mempengaruhi hubungan antara penerapan akuntansi pertanggungjawaban dengan efektivitas pengendalian biaya.

Berdasarkan hasil uji tersebut maka didapatkan hasil bahwa variabel akuntansi pertanggungjawaban berpengaruh positif terhadap pengendalian biaya. Dengan demikian disimpulkan bahwa hipotesis pertama $\left(\mathrm{H}_{1}\right)$ diterima yaitu, penerapan akuntansi pertanggungjawaban berpengaruh positif pada efektivitas pengendalian biaya. Hal tersebut bermakna semakin baik pertanggungjawaban yang dilakukan, maka akan meningkatkan efektivitas pengendalian biaya yang dilakukan. Hasil tersebut sesuai dengan teori agensi yang menyatakan bahwa adanya perbedaan kepentingan antara pihak yang memberi wewenang. Dalam akuntansi pertanggungjawaban, perbedaan kepentingan terjadi pada setiap pusat-pusat pertanggungjawaban. Maka dari itu, perlu adanya peran akuntansi pertanggungjawaban. Dengan diterapkannya akuntansi pertanggungjawaban, maka efektivitas pengendalian biaya akan lebih mudah terwujud.

Penelitian ini sesuai dengan penelitian yang dilakukan oleh Ardiani \& Wirasedana (2013) yang menguji pengaruh penerapan akuntansi pertanggungjawaban terhadap efektivitas pengendalian biaya, didapatkan hasil bahwa terdapat hubungan positif antara penerapan akuntansi pertanggungjawaban dengan efektivitas pengendalian biaya. Selain itu didukung juga dengan penelitian yang dilakukan oleh Bahtiar (2013) yang menguji hubungan akuntansi pertanggungjawaban dengan efektivitas pengendalian biaya juga menunjukkan bahwa adanya hubungan positif antara penerapan akuntansi pertanggungjawaban dengan pengendalian biaya. Hal ini menunjukkan bahwa akuntansi pertanggungjawaban mampu membantu dan mempermudah manajer dalam proses evaluasi hasil kerja pada masing-masing pusat pertanggungjawaban dalam usaha untuk mencapai tujuan perusahaan dan manajemen yang lebih baik.

Selain itu variabel motivasi kerja mempengaruhi hubungan antara penerapan akuntansi pertanggungjawaban dan efektivitas pengendalian biaya. 
Dengan demikian, maka hipotesis kedua $\left(\mathrm{H}_{2}\right)$ diterima yaitu motivasi kerja mampu memoderasi pengaruh penerapan akuntansi pertanggungjawaban pada efektivitas pengendalian biaya. Pengaruh yang ditimbulkan adalah memperkuat hubungan antara akuntansi pertanggungjawaban pada efektivitas pengendalian biaya. Motivasi kerja adalah sesuatu yang menimbulkan dorongan atau semangat kerja yang dipengaruhi oleh beberapa faktor, antara lain atasan, sarana fisik, kebijaksanaan, peraturan, imbalan jasa uang dan non uang, jenis pekerjaan dan tantangan (Samsudin, 2010). Sesuai dengan Goal Setting Theory yang menjelaskan mengenai pentingnya hubungan tujuan yang diharapkan organisasi dengan kinerja yang dihasilkan. Sasaran dapat dipandang sebagai tujuan atau tingkat kinerja yang ingin dicapai oleh individu. Sehingga setiap individu memiliki tanggung jawab masing-masing yang harus di selesaikan, guna mencapai tujuan perusahaan. Dengan adanya tujuan perusahaan ataupun sasaran yang ingin dicapai, maka dapat mempengaruhi motivasi individu untuk mencapai tujuan yang ditetapkan. Tujuan ataupun sasaran perusahaan yang ingin dicapai yaitu mendapatkan laba. Sehingga dalam usaha mencapai laba serta pengendalian biaya yang memadai, diperlukan adanya motivasi kerja. Hal ini menunjukkan bahwa motivasi kerja mampu mempengaruhi kinerja karyawan dalam mencapai tujuan perusahaan yakni tercapainya efektivitas pengendalian biaya. Penelitian yang dilakukan oleh Anggarini \& Sujana (2016) mendapatkan hasil bahwa motivasi berpengaruh positif pada hubungan antara partisipasi anggaran pada kinerja manajerial. Serta menunjukkan variabel motivasi mampu memoderasi dan memperkuat hubungan antara partisipasi anggaran terhadap kinerja manajerial. Selain itu, penelitian Dewi \& Ferayani (2019) mengenai motivasi memoderasi pengaruh sistem pengendalian intern dan partisipasi penyusunan anggaran pada kinerja individu, mendapatkan hasil bahwa motivasi kerja mampu memperkuat hubungan sistem pengendalian intern dan keikutsertaan dalam menyusun anggaran pada kinerja individu.

\section{SIMPULAN}

Berdasarkan pada hasil analisis dan pembahasan pada hasil penelitian ini dapat ditarik beberapa kesimpulan yakni Akuntansi pertanggungjawaban berpengaruh positif pada efektivitas pengendalian biaya. Hal ini mengartikan bahwa semakin baik penerapan akuntansi pertanggungjawaban, maka semakin efektif pengendalian biaya yang dilakukan oleh Arta Sedana Supermarket \& Departement Store dan Harum Fajar. Serta motivasi kerja merupakan variabel yang memoderasi pengaruh penerapan akuntansi pertanggungjawaban pada efektivitas pengendalian biaya yang dilakukan oleh Arta Sedana Supermarket \& Departement Store dan Harum Fajar. Hal ini berarti, ketika diterapkannya akuntansi pertanggungjawaban dan semakin tinggi motivasi karyawan untuk melakukan tanggungjawabnya, maka semakin tinggi efektivitas pengendalian biaya yang dihasilkan. Peneliti selanjutnya dapat menguji variabel lainnya yang mungkin memengaruhi efektivitas pengendalian biaya selain akuntansi pertanggungjawaban dan motivasi kerja. Variabel yang dapat mempengaruhi pengendalian biaya, misalnya variabel budaya organisasi ataupun komitmen karyawan. 


\section{REFERENSI}

Al-shomali, I. (2013). Performance Evaluation and Responsibility Accounting. Journal of Management Research, 5(1), 291-301.

Andani, K. N., Sujana, E., \& Sulindawati, N. L. G. E. (2017). Analisis Pengaruh Penerapan Akuntansi Pertanggungjawaban Terhadap Kinerja Perusahaan Dengan Motivasi Kerja Sebagai Variabel Moderasi. E-Journal S1 Ak Universitas Pendidikan Ganesha, 7(1).

Andriana, D., \& Balqis, K. (2015). Peranan Akuntansi Pertanggungjawaban Dalam Kinerja Manajer Pusat Pertanggungjawaban (Studi Kasus Pada Produk Manufaktur PT. PINDAD (Persero)). Jurnal Riset Akuntansi Dan Keuangan, 3(1), 649-659.

Anggarini, N. N. D., \& Sujana, I. K. (2016). Pengaruh Partisipasi Anggaran Pada Kinerja Manajerial PT. BPD Bali Cabang Tabanan: Motivasi Sebagai Variabel Pemoderasi. E-Jurnal Akuntansi Universitas Udayana, 14(1), 66-78.

Anthony, R., \& Govindarajan, V. (2005). Sistem Pengendalian Manajemen, Terjemahan J F.X Kurniawan Tjakrawala dan Krista. Jakarta: Salemba Empat.

Ardiani, N. M. S., \& Wirasedana, I. W. P. (2013). Pengaruh penerapan akuntansi pertanggungjawaban terhadap efektivitas pengendalian biaya. E-Jurnal Akuntansi Universitas Udayana, 5(3), 561-573.

Arthana, I. M., Mimba, N. P. S. H., \& Wirakusuma, M. G. (2016). Kejelasan Sasaran Anggaran dan Komitmen Organisasi Sebagai Pemoderasi Pengaruh Kompetensi Pegawai Pada Kinerja Penyerapan Anggaran. E-Jurnal Ekonomi Dan Bisnis Universitas Udayana, 5(5), 1143-1170.

Bahtiar, E. (2013). Hubungan Akuntansi Pertanggungjawaban Dengan Efektivitas Pengendalian Biaya (Studi Kasus PT.Columbia Cabang Gorontalo), 1-16.

Brownell, P. (1982). The Role of Accounting Data in Performance Evaluation, Budgetary Participation, and Organizational Effectiveness. Journal of Accounting Research, 20(1), 12-27.

D. Watung, T., Saerang, D. P. E., \& Mawikere, L. (2014). Penerapan Akuntansi Pertanggungjawaban Untuk Penilaian Kinerja Manajerial Pada PT. Tirta Investama (DC) Manado. Jurnal EMBA, 2(2), 1539-1549.

Damayanti, E. (2004). Penerapan Akuntansi Pertanggungjawaban Melalui Pusat Biaya Sebagai Alat Pengendalian Manajemen Pada PT. Pos Indonesia. Jurnal Ekonomi Dan Bisnis, 2(9), 84-97.

Dewi, M. S., \& Ferayani, M. D. (2019). Motivasi Memoderasi Pengaruh Sistem Pengendalian Intern Dan Partisipasi Penyusunan Anggaran Pada Kinerja Individu.

Effendy, M. V., Mahsina, \& Susanti, W. (2015). Analisis Akuntansu Pertanggungjawaban Sebagai Alat Pengendalian dan Evaluasi Kinerja Menejemen (PT. Asuransi Jiwasraya Malang). Jurnal Ekonomi Akuntansi Equity, 87-96.

Fowzia, R. (2011). Use of Responsibility Accounting and Measure the Satisfaction Levels of Service Organizations in Bangladesh. International Review of Business Research, 7(5), 53-67.

Hafidz, A. R. (2007). Peranan Anggaran Biaya Operasi Dalam Menunjang Efektivitas Pengendalian Biaya. Retrieved from http:// repository.widyatama.ac.id/xmlui/handle/10364/514, 
Jensen, M. C., \& Meckling, W. H. (1976). Theory Of The Firm: Managerial Behavior, Agency Costs and Ownership Structure. Journal of Financial Economics, 3(4), 305-360. https:/ / doi.org/10.1016/0304-405X(76)90026-X

Lau, C. M., \& Tan, S. L. C. (2003). The Effects of Participation and Job Relevant Information on the Relationship Between Evaluative Style and Job Satisfaction. Review of Quantitative Finance and Accounting, 21(1), 17-34.

Locke, E. A. (1978). The Ubiquity of Technique of Goal Setting in Theories of and Approaches Employee Motivation. Academy of Management Review, 3(3), 594601.

Mia, L. (1988). Managerial Attitude Motivation and The Effectiveness of Budget Participation. Accounting Organizations and Society, 13(5), 465-475.

Napitupulu, M. D. M., \& Widodo, H. S. (2014). Pengaruh Akuntansi Pertanggungjawaban Terhadap Motivasi Manajer, 1-11.

Novitasari, N., \& Wirama, D. G. (2016). Pengaruh Pengendalian Anggaran Pada Senjangan Anggaran dan Orientasi Jangka Pendek Manajer. E-Jurnal Akuntansi Universitas Udayana, 15(3), 2024-2051.

Nyakuwanika, M., Gutu, G. J., Zhou, S., Tagwireyi, F., \& Chidoko, C. (2012). An Analysis of Effective Responsibility Accounting System Strategies in the Zimbabwean Health Sector ( 2003-2011 ). Research Journal of Finance and Accounting, 3(8), 86-92.

Pomes, L. (2016). Pengaruh Akuntansi Pertanggungjawaban Terhadap Efektivitas Pengendalian Biaya, 5(2), 37-43.

Prang, O. S. (2014). Penerapan Akuntansi Pertanggungjawaban Dengan Anggaran Sebagai Alat Pengendalian Untuk Penilaian Kinerja Pada PT. Pelayaran Nasional Indonesia Cabang Bitung, 1(4), 1016-1024.

Safa, M. (2012). Examining the Role of Responsibility Accounting in organizational Structure. American Academic and Scholarly Research Journal, $4(5)$.

Samsudin, S. (2010). Manajemen Sumber Daya Manusia. Bandung: Pustaka Setia.

Setiyanto, A. I., \& Norafyana. (2017). Pengaruh Penerapan Akuntansi Pertanggungjawaban Terhadap Pengendalian Biaya Pada Industri Manufaktur Di Batam, 9(1), 45-54.

Sholihin, M., Pike, R., \& Mangena, M. (2010). Reliance On Multiple Performance Measures and Manager Performance. Journal of Applied Accounting, 11(1), 2442. https:/ / doi.org/10.1108/09675421011050018

Sinambela, L. P. (2010). Kinerja Pegawai Teori Pengukuran dan Implikasi. Yogyakarta: Graha Ilmu.

Siyanbola, T. T., \& Raji, G. M. (2013). The Impact of Cost Control on Manufacturing Industries' Profitability, 2(4).

Sosik, J. J., Juzbasich, J., \& Uk, J. (2011). Effects Of Moral Reasoning and Management Level On Ratings Of Charismatic Leadership, In Role and Extra Role Performance Of Managers: A Multi Source Examination. The Leadership Quarterly, 22(2), 434-450. https:// doi.org/10.1016/j.leaqua.2011.02.015

Sriwidodo, U. (2010). Informasi Akuntansi Pertanggungjawaban Sebagai Alat Penilaian Kinerja Manajer, 8(1), 18-24.

Wei, Y., Wang, L., Liao, H., Wang, K., Murty, T., \& Yan, J. (2014). Responsibility 
Accounting in Carbon Allocation: A Global Perspective, 122-133. https:// doi.org/10.1016/j.apenergy.2014.05.025

Wentzel, K. (2002). The Influence of Fairness Perceptions and Goal Commitment on Managers ' Performance in a Budget Setting, 14.

Zaim, H., Yasar, M. F., \& Unal, O. F. (2013). Analyzing The Effects Of Individual Competencies On Performance: A Field Study In Services Industries In Turkey. https://doi.org/10.20460/JGSM.2013715668 